\title{
Gold(I)-catalyzed enantioselective cycloaddition reactions
}

\author{
Fernando López ${ }^{* 1, \S}$ and José L. Mascareñas ${ }^{* 2, \pi}$
}

\section{Review}

\section{Address:}

${ }^{1}$ Instituto de Química Orgánica General, CSIC and Centro Singular de Investigación en Química Biolóxica e Materiais Moleculares (CIQUS). Universidade de Santiago de Compostela, 15782, Santiago de Compostela, Spain and ${ }^{2}$ Departamento de Química Orgánica, Centro Singular de Investigación en Química Biolóxica e Materiais Moleculares (CIQUS). Universidade de Santiago de Compostela, 15782, Santiago de Compostela, Spain

\section{Email:}

Fernando López* - fernando.lopez@csic.es; José L. Mascareñas* joseluis.mascarenas@usc.es

* Corresponding author

§ phone: (+) 34 881815781; fax: (+) 34981595012

II phone: (+) 34981563100 Fax: (+) 34981595012

Keywords:

alkyne; allene; asymmetric catalysis; cycloaddition; enantioselective; gold; gold catalysis

\begin{abstract}
Beilstein J. Org. Chem. 2013, 9, 2250-2264.
\end{abstract}
doi:10.3762/bjoc.9.264

Received: 16 July 2013

Accepted: 26 September 2013

Published: 30 October 2013

This article is part of the Thematic Series "Gold catalysis for organic synthesis II".

Guest Editor: F. D. Toste

C 2013 López and Mascareñas; licensee Beilstein-Institut. License and terms: see end of document.

\begin{abstract} and key intermediates involved in the processes.

\section{Introduction}

In the past decade, there have been extraordinary advances in the development of novel stereoselective gold(I)-catalyzed transformations [1-10]. In this context, enantioselective gold catalysis has been identified as a particularly challenging goal because the linear two-coordination mode of gold(I) complexes and the out-sphere $\pi$-activation usually associated to carbophilic gold catalysts [11] places ligands far from the reacting centers, thus limiting the capacity to transfer asymmetry [12].
\end{abstract}

In recent years there have been extraordinary developments of gold(I)-catalyzed enantioselective processes. This includes progress in the area of cycloaddition reactions, which are of particular interest due to their potential for the rapid construction of optically active cyclic products. In this article we will summarize some of the most remarkable examples, emphasizing reaction mechanisms
A number of strategies to tackle this problem have been developed, most of them based on the use of a new type of chiral gold complexes. This resulted in a number of gold-catalyzed enantioselective transformations in the past years, including hydrogenations, aldol reactions, 1,3-dipolar cycloadditions, and cyclizations [13-15]. Other gold-promoted asymmetric induction strategies rely on the use of chiral counterions. Indeed, it has been shown that a tight chiral ion pair with the gold cation 
is able to induce excellent levels of asymmetry in certain cyclizations [16].

Cycloaddition reactions are very important synthetic processes that allow the transformation of simple acyclic precursors into complex cyclic or polycyclic adducts in a rapid and efficient way $[17,18]$, usually providing a rapid increase in skeletal and stereochemical complexity. Moreover, cycloadditions are atom economical, and usually take place with high levels of regioand stereocontrol. Especially relevant in terms of synthetic practicality are cycloadditions which are catalyzed by transition metal complexes [19-23]. In particular, gold(I) complexes, owing to their high carbophilicity, low oxophilicity and high oxidation potential between gold(I) and gold(III) have shown a unique potential to unveil novel types of chemoselective and stereoselective cycloadditions involving alkynes, allenes or alkenes [24-26].

A lot of interest has been directed to the development of these cycloaddition processes in an enantioselective manner, so that the resulting cyclic products could be obtained in an optically pure fashion [27]. Herein, we describe the most relevant types of enantioselective cycloaddition reactions based on the use of carbophilic gold(I) complexes. We do not consider cycloaddition reactions in which the gold complex acts more like a conventional Lewis acid rather than by activating $\pi$-bonds [2832]. The reactions included in this review are classified according to the type of key reactive gold intermediates that formally participate in the cycloaddition. Thus, we will present cycloaddition processes (i) with a gold-carbene intermediate, (ii) involving an allene activation to generate a gold-allyl cationic intermediate and, (iii) in which the proposed key reactant is a vinylgold zwitterionic species.

\section{Review \\ Cycloadditions involving gold-carbene inter- mediates}

Gold-carbene species are frequent intermediates in goldcatalyzed reactions, in particular those involving alkynes [3337]. Gold(I) catalysts bind chemoselectively to $\mathrm{C}-\mathrm{C}$ triple bonds, promoting the attack of different types of nucleophiles on these electrophilic species. Depending on the particular system, the resulting vinylgold intermediates can be externally trapped or evolve to reactive carbene species. This is the case for propargyl esters (Figure 1), as these systems usually undergo 1,2 or 1,3-acyloxy migrations in the presence of gold catalysts. Such migrations proceed via a nucleophilic intramolecular attack of the carboxy moiety on the activated alkyne. 1,2-Migration of the ester affording a gold-carbene of type $\mathbf{A}$ is usually preferred when a terminal alkyne is used [3840].

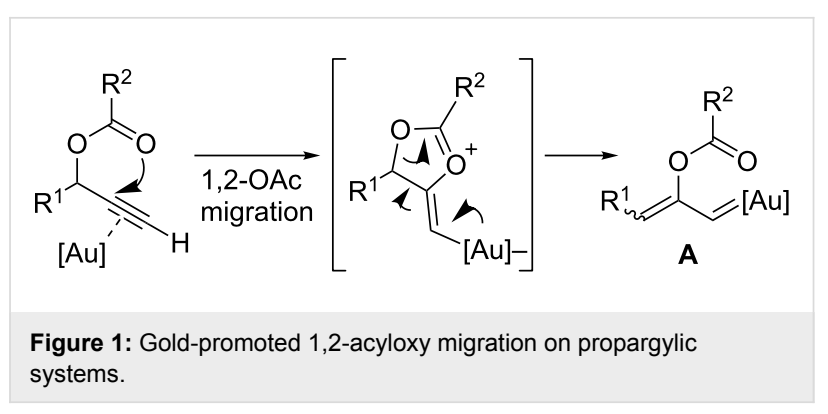

Based on this concept, several groups have shown that the resulting carbenoid intermediates of type $\mathbf{A}$ can engage in different types of cycloaddition reactions with diverse $\mathrm{C}-\mathrm{C}$ unsaturated systems. Here, we discuss the systems for which an enantioselective variant has been developed.

In 2005, Toste and coworkers described one of the first goldcatalyzed enantioselective processes that could be formally categorized as a $[2+1]$ cycloaddition. In particular, they showed that it is possible to trap the intermediate gold-carbenes resulting from a 1,2-acyloxy migration in propargyl esters such as $\mathbf{1}$, with external alkenes (e.g. vinylarenes), to give cyclopropane products [41]. The racemic variant of the method, which employs $\mathrm{Ph}_{3} \mathrm{PAuCl} / \mathrm{AgSbF}_{6}$ as a catalyst, predominantly affords cis-cyclopropane adducts of type $\mathbf{2}$, and tolerates a wide range of olefin substituents. Importantly, the authors demonstrated that the process could also be rendered enantioselective by using a chiral bisgold complex derived from DTBMSegphos (Au1). High or even very high levels of enantioselectivity could be achieved when the propargylic system features sterically demanding esters such as pivaloates, or the alkene component presents large aromatic substituents. In all these cases the reaction afforded the cis isomer with high diastereoselectivity. Moreover, the enantioselective cyclopropanation was not limited to arylated olefins (e.g. styrenes), but allyltrimethylsilane also participated in the process, producing the corresponding silylmethyl cyclopropane as a 5:1 mixture of cis:trans isomers with a good $78 \%$ ee (Scheme 1).

In 2009 , the same group extended the utility of this asymmetric cyclopropanation reaction to an intramolecular process that allows the enantioselective synthesis of polycarbocyclic products embedding seven or eight-membered rings [42]. Curiously, the catalytic system based on DTBM-Segphos, which was particularly successful in the abovementioned intermolecular cases, only provided good enantioselectivities in the case of systems affording products with seven-membered rings (3, $n=0$, Scheme 2). For the eight-membered counterparts, the authors found that a related bisphosphine-gold catalyst, XylylBinap $(\mathrm{AuCl})_{2} / \mathrm{AgSbF}_{6}$ was more efficient, facilitating good yields of the corresponding products and enantioselectivities 
<smiles>C#CC(=O)OC(C)(C)C</smiles>

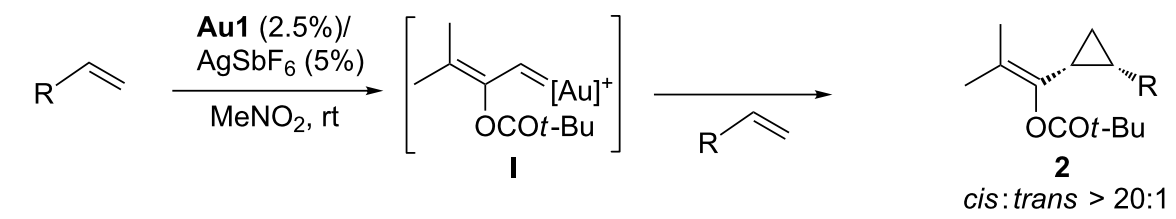

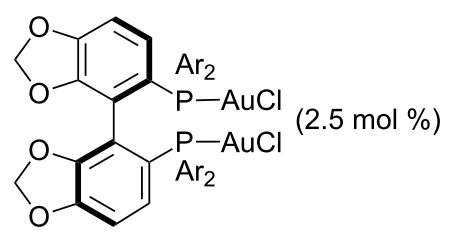

Au1: $\mathrm{Ar}=3,5-t-\mathrm{Bu}-4-(\mathrm{MeO})-\mathrm{C}_{6} \mathrm{H}_{2}$ $(R)$-DTBM-Segphos $(\mathrm{AuCl})_{2}$

\begin{tabular}{lrl}
\hline $\mathrm{R}$ & yield & ee \\
\hline $\mathrm{Ph}$ & $70 \%$ & $81 \%$ \\
2-Me-Ph & $83 \%$ & $87 \%$ \\
4- $t$-Bu-Ph & $82 \%$ & $81 \%$ \\
2,6-Me-4-t-Bu-Ph & $71 \%$ & $94 \%$ \\
1-naphthyl & $79 \%$ & $85 \%$ \\
$\mathrm{CH}_{2} \mathrm{SiMe}_{3}{ }^{\text {[a] }}$ & $74 \%$ & $78 \%$ \\
\hline
\end{tabular}

${ }^{[a]}$ cis : trans $=5: 1$

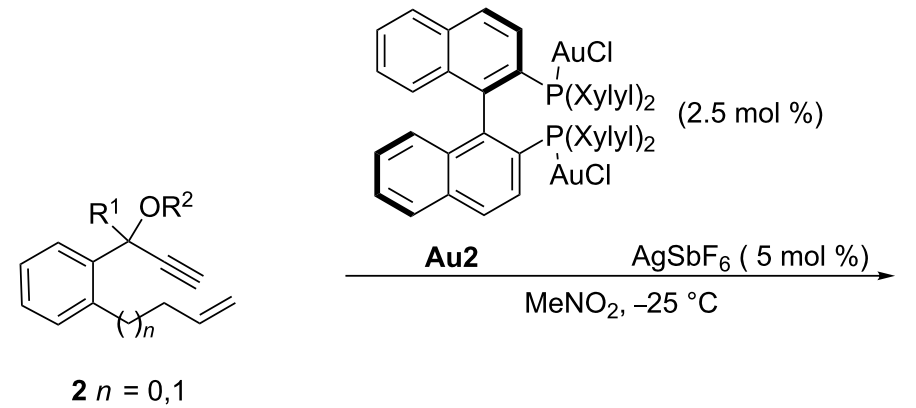

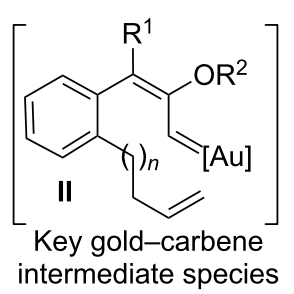<smiles>[R1]C1=C([R17])[C@H]2C[C@@H]2C[C@@H]2CC12</smiles>

3

Scheme 2: Gold-catalyzed enantioselective intramolecular cyclopropanation

between 75 and $92 \%$. In these cases, the bulky pivaloate at the propargylic position led to lower enantioselectivites than a less congested acetate group, showcasing that a fine-tuning of the catalyst and substrate is required to achieve excellent enantioselectivities.

More recently, Nevado and co-workers have shown that propargyl acetates 4 react with 1,3-dienes in the presence of a gold catalyst to give good yields of cycloheptadiene products of type 5; thus the process could be formally considered as a $[4+3]$ annulation. A possible mechanism would involve a gold-mediated 1,2-acyloxy migration of the propargyl ester to generate a gold-carbene species III which cyclopropanates a $\mathrm{C}-\mathrm{C}$ double bond of the diene to form a cis-cyclopropane intermediate IV. A subsequent gold-catalyzed Cope rearrangement through a boat-like transition state would deliver the cis-2,3-disubstituted cycloheptenyl acetates of type $\mathbf{5}$ (Scheme 3) [43].

Although the process was essentially developed in a racemic fashion, by using $\mathbf{A u 3} / \mathrm{AgSbF}_{6}$ or a combination of $\mathbf{A u 4}$ and $(\mathrm{PhO})_{3} \mathrm{PAuSbF}_{6}$ (Scheme 3), the authors also demonstrated the feasibility of an enantioselective variant. Thus, treatment of pivaloate 4a with 6,6-dimethyl-1-vinylcyclohexene in the 


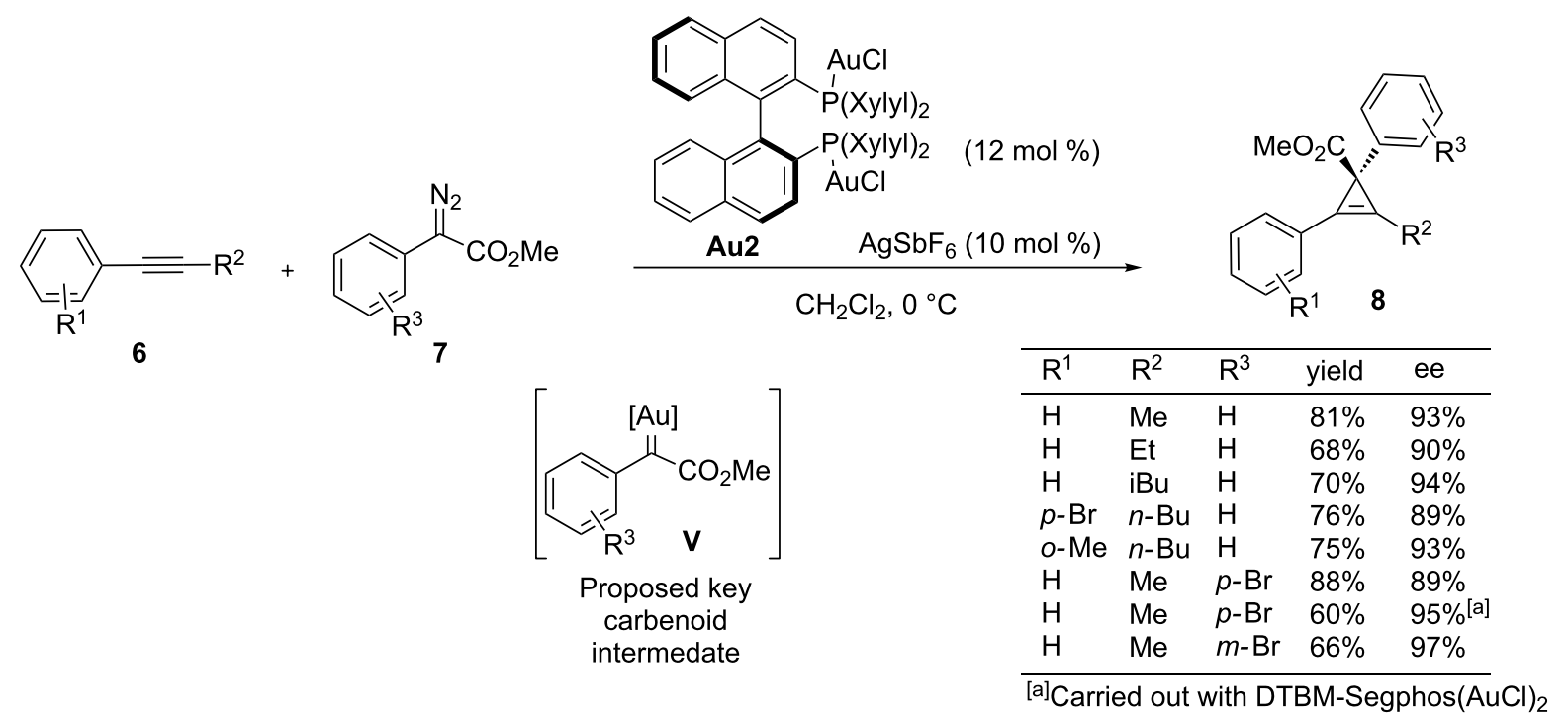

Scheme 5: Gold(I)-catalyzed enantioselective cyclopropenation of alkynes.

particular, the authors demonstrated that the chiral bisgold complex Au6, derived from the spiroketal bisphosphine ligand, was a very efficient promoter of the cyclopropanation between donor-acceptor diazooxindoles such as $\mathbf{9}$ and a broad range of alkenes (Scheme 6) [47]. The resulting spirocyclopropyloxindoles 10, which are obtained in excellent yields and enantioselectivities, are appealing structures from a medicinal point of view. The scope of the alkene is quite remarkable, since not only monosubstituted and 1,1-disubstituted olefins participated in the cyclopropanation, but also 1,2-disubstituted alkenes (cis or trans), which previously failed with other chiral transition metal catalysts, providing excellent yields and very good levels of enantioselectivity.

\section{Cycloadditions initiated by activation of allenes}

Gold(I) catalysts can efficiently activate allenes in a highly chemoselective way, triggering the formation of allenyl cationic species. Different structures have been proposed to represent these gold-activated allene complexes, including $\eta^{2}$-complexes

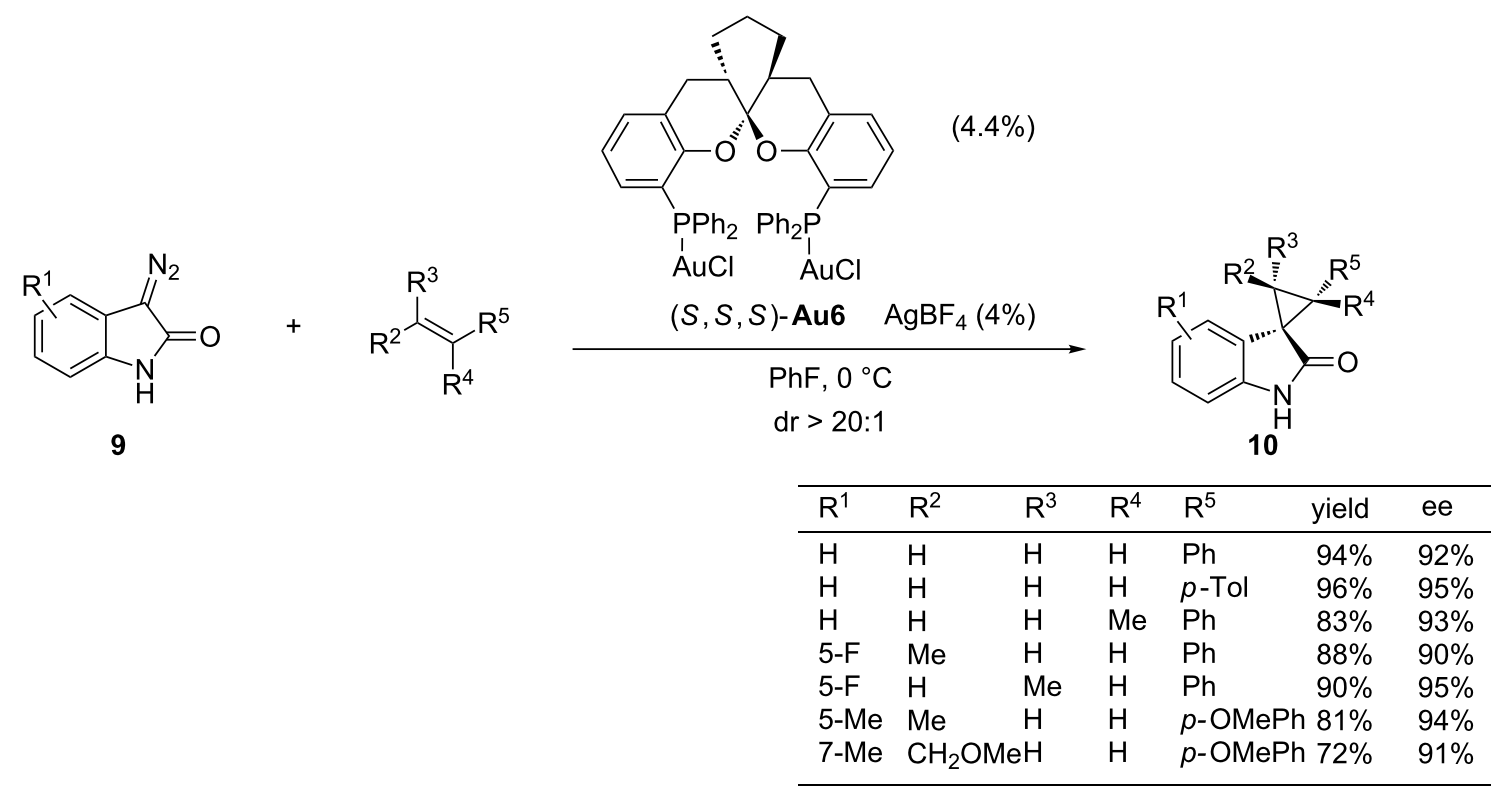


$(\mathbf{B}, \mathbf{B}$ ' and B', ), planar $\sigma$-allylic cations $\mathbf{C}$, zwitterionic carbenes $\mathbf{C}^{\prime}$ or $\eta^{1}$-bent allenes $\mathbf{C}$ ', (Figure 2) [48]. In some cases, experimental and theoretical evidence supports the participation of one of those structures, but in many other cases the precise nature of these species remains unknown. The gold-activated allene complexes have been shown to participate in a great variety of intra- and intermolecular cycloaddition reactions, including $[4+3],[4+2],[3+3],[3+2]$ or $[2+2]$ annulation processes [1-10,24-26]. Particular attention has been paid during the last years to the development of enantioselective versions of these processes by using chiral gold catalysts. In this section, we highlight the most important developments in this area.

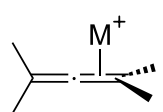

B

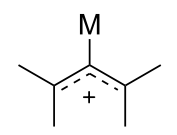

C

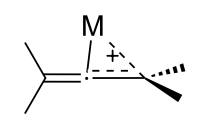

$\mathbf{B}^{\prime}$

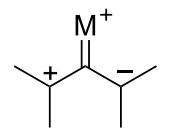

$C^{\prime}$

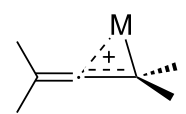

B"

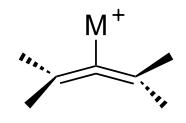

$C^{\prime \prime}$
Figure 2: Proposed structures for gold-activated allene complexes.
In 2007, Toste and coworkers described an intramolecular [2+2] cycloaddition of allenenes by using gold catalysts [49]. The proposed mechanism is based on the generation of a gold(I)-activated allene, which undergoes a cyclization to give a new carbocationic species of type VI (Scheme 7) [50,51]. A subsequent ring closure provides the observed bicyclo[3.2.0] systems of type 12, featuring a four-membered carbocycle. These reactions, which are efficiently promoted by $\mathrm{Ph}_{3} \mathrm{PAu}^{+} \mathrm{BF}_{4}$ in their racemic variants, could be performed in a highly enantioselective manner with gold catalysts containing a DTBM-Segphos ligand. Enantioselectivities ranged from 54 to $96 \%$, and seem to be highly dependent on the tether that links the allene and the alkene moieties. Thus, the reaction proved to be efficient for substrates containing tethers with geminal diesters, whereas those containing $N$-tosyl-based tethers led to significantly lower enantioselectivities. However, the same group more recently demonstrated that a chiral phosphoramidite-gold complex, such as Au7, could eventually solve this limitation, leading to a complementary reactivity to that exhibited by DTBM-Segphos $(\mathrm{AuCl})_{2} / \mathrm{AgBF}_{4}$ in terms of substrate scope, and affording enantioselectivities up to $97 \%$ (Scheme 6) [51]. Additionally, Fürstner and co-workers have also demonstrated that a phosphoramidite-gold complex like Au8, containing an acyclic Taddol-based backbone, was also an excellent catalyst to perform the same type of $[2+2]$ cycloadditions of allenenes $\mathbf{1 1}[52,53]$. This catalyst performs equally

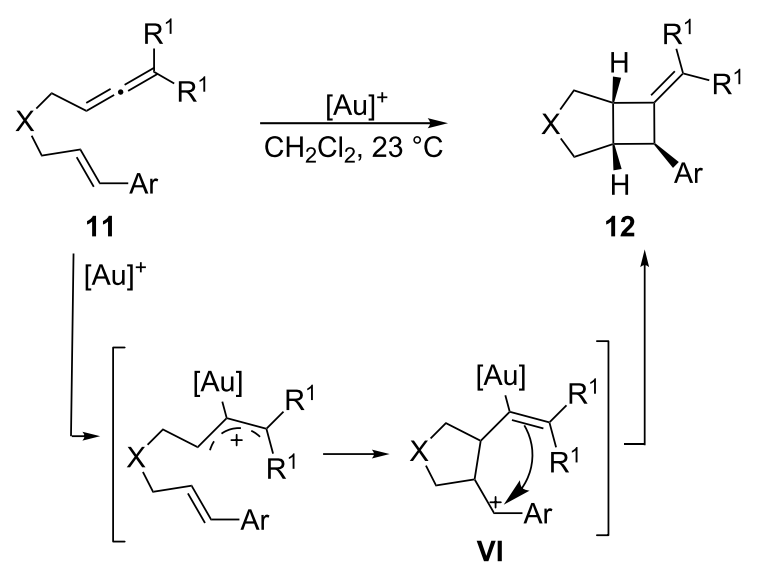

\begin{tabular}{lllll}
\hline $\mathrm{X}$ & $\mathrm{R}^{1}$ & $\mathrm{Ar}$ & yield & ee \\
\hline $\mathrm{C}\left(\mathrm{CO}_{2} \mathrm{Me}\right)_{2}$ & $\mathrm{Me}$ & $\mathrm{Ph}$ & $92 \%$ & $95 \%\left[\%^{[\mathrm{a}]}\right.$ \\
$\mathrm{C}\left(\mathrm{CO}_{2} \mathrm{Me}\right)_{2}$ & $\mathrm{Me}$ & $\mathrm{Ph}$ & $75 \%$ & $14 \% \%^{[\mathrm{b}]}$ \\
$\mathrm{C}\left(\mathrm{CO}_{2} \mathrm{Me}\right)_{2}$ & $\mathrm{Me}$ & $\mathrm{Ph}$ & $91 \%$ & $99 \% \%^{[c]}$ \\
$\mathrm{NTs}$ & $\mathrm{Me}$ & $\mathrm{Ph}$ & $70 \%$ & $54 \%{ }^{[\mathrm{a}]}$ \\
$\mathrm{NTs}$ & $\mathrm{Me}$ & $\mathrm{Ph}$ & $86 \%$ & $94 \% \%^{[\mathrm{b}]}$ \\
$\mathrm{NTs}$ & $\mathrm{Me}$ & $\mathrm{Ph}$ & $52 \%$ & $95 \% \%^{[\mathrm{c}]}$ \\
$\mathrm{C}\left(\mathrm{SO}_{2} \mathrm{Ph}\right)_{2}$ & $\mathrm{Me}$ & $\mathrm{Ph}$ & $82 \%$ & $85 \%^{[\mathrm{b}]}$ \\
$\mathrm{C}\left(\mathrm{SO}_{2} \mathrm{Ph}\right)_{2}$ & $\mathrm{Me}$ & $\mathrm{Ph}$ & $60 \%$ & $81 \% \%^{[\mathrm{c}]}$ \\
$\mathrm{C}\left(\mathrm{CO}_{2} \mathrm{Me}\right)_{2}$ & $\mathrm{Me}$ & $2-\mathrm{Napht}$ & $87 \%$ & $98 \% \%^{[\mathrm{c}]}$ \\
$\mathrm{C}\left(\mathrm{CO}_{2} \mathrm{Me}\right)_{2}$ & $\left(-\mathrm{CH}_{2}\right)_{5}$ & $\mathrm{Ph}$ & $93 \%$ & $99 \%{ }^{[\mathrm{c}]}$ \\
\hline
\end{tabular}

[a]With DTBM-Segphos $(\mathrm{AuCl})_{2}(3 \%) / \mathrm{AgBF}_{4}(6 \%)$, $\mathrm{CH}_{2} \mathrm{Cl}_{2}, 4{ }^{\circ} \mathrm{C}$; ${ }^{[\mathrm{b}]}$ with Au7 $(5 \%) / \mathrm{AgBF}_{4}(5 \%), \mathrm{CH}_{2} \mathrm{Cl}_{2}$, $25{ }^{\circ} \mathrm{C}$; ${ }^{[\mathrm{C}]}$ with $\mathrm{Au} 8(5.5 \%) / \mathrm{AgBF}_{4}(5 \%), \mathrm{CH}_{2} \mathrm{Cl}_{2}, 0^{\circ} \mathrm{C}$ or rt.

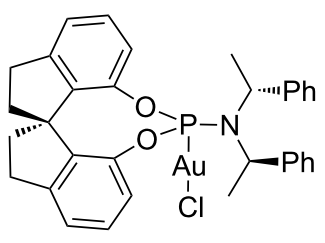

$(R, R, R)$-Au7

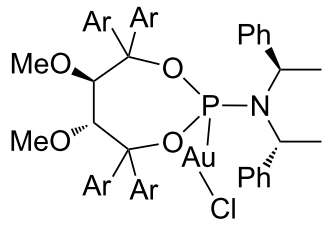

$(R, R, R, R)$-Au8 $\mathrm{Ar}:$ 4-t-Bu-Ph 
well with carbon-based and nitrogen-based tethers, and excellent levels of asymmetric induction were obtained from a set of representative examples, including those with structural modifications at the allene and alkene sites (Scheme 7).

Early in 2008, our group demonstrated the possibility of using gold-activated allenes as allyl cation surrogates capable of participating in concerted $[4 \mathrm{C}(4 \pi)+3 \mathrm{C}(2 \pi)]$ cycloadditions with conjugated dienes [54], a process related to the classical oxyallyl cation [4 +3 ] cycloadditions [55-57]. An initial screening demonstrated that $\mathrm{PtCl}_{2}$ was a good catalyst for promoting these intramolecular $[4 \mathrm{C}+3 \mathrm{C}]$ cycloadditions [54] Further studies revealed that the scope of the methodology could be significantly broadened by using a gold catalyst such as $\mathbf{A u 9} / \mathrm{AgSbF}_{6}$ [58]. In general, the reactions are completely diastereoselective, affording bicyclo[5.3.0]decane products (14 and/or 14') that result from an exo-like approach of the allyl cation to the diene. Curiously, by using a gold(I) catalyst bearing a $\pi$-acceptor phosphite ligand, such as $\mathbf{A u 1 0} / \mathrm{AgSbF}_{6}$, allenedienes disubstituted at the distal position of the allene lead to products formally arising from a [4 +2$]$ cycloaddition process (Scheme 8, b) $[59,60]$. Several experimental data as well as theoretical calculations suggested that both cycloadducts, 14 and 15, arise from the same intermediate, the cycloheptanyl metal-carbene species VIII, which might evolve through a 1,2-hydrogen shift to give the seven-membered carbocycles 14 (Scheme 8, a), or by a ring-contraction process to give the cyclohexenyl products (Scheme 8, b) [60-64]. There- fore, the ligand at gold, as well as the type of substituents at the allene terminus, determine the fate of this carbene and hence the formation of the $[4+3](\mathbf{1 4})$ or $[4+2](\mathbf{1 5})$ cycloadducts.

The development of enantioselective versions of these two cycloadditions was actively pursued by several groups. The electronic similarity between phosphites and phosphoramidites suggested that chiral gold complexes of these highly modular monodentate ligands [65] could be good candidates to promote enantioselective variants of the $[4+2]$ cycloaddition (Scheme 9, $\mathrm{R}^{1}, \mathrm{R}^{2}=$ alkyl groups). This turned out to be the case and, gratifyingly, we showed that it is possible to perform highly enantioselective allenediene $[4+2]$ cycloadditions by using gold complexes derived from a bulky phosphoramidite equipped with anthracenyl substituents at the Binol ortho-positions (Au11, Scheme 9) [60]. Independently, Toste and co-workers reported that the related phosphoramidite-gold complex Au12, and the chiral gold catalyst Au13, derived from a $C_{3}$-symmetric phosphite [66], were also able to induce excellent enantioselectivities in these [4 +2$]$ cycloadditions [67]. Moreover, Fürstner and co-workers also showed that the Taddol-based phosphoramidite-gold complex Au8, which was effective in the $[2+2]$ cycloadditions of allenenes, was also able to induce good enantioselectivities in these higher order annulations (Scheme 9) [52].

Although $\pi$-acceptor ligands, such as phosphites or phosphoramidites favor the formation of the $[4+2]$ adduct of type $\mathbf{1 5}$,

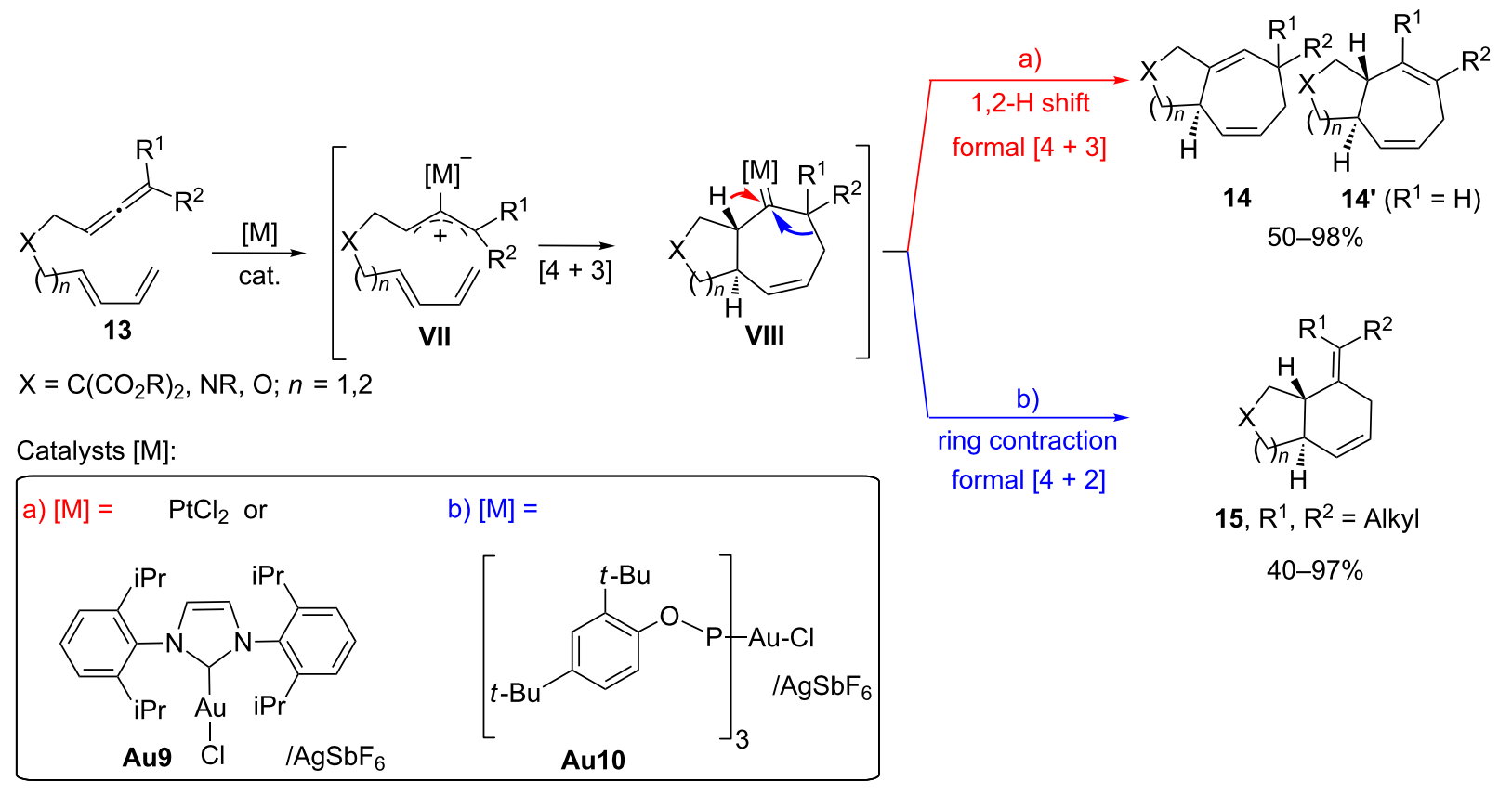

Scheme 8: Gold-catalyzed allenediene [4 +3$]$ and [4 +2$]$ cycloadditions. 
<smiles>[Y]C/C=C\C=C/C=C([R])[R]</smiles>

13

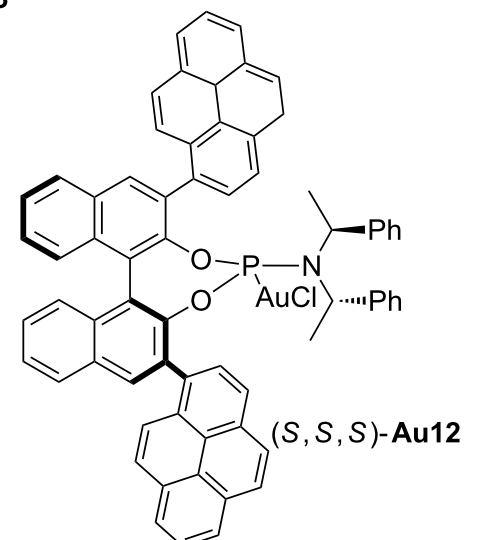<smiles>COP(F)(=S)Oc1ccc2c(c1-c1c(OC(=O)C34CC5CC(CC(C5)C3)C4)ccc3c1CCCC3)CCCC2</smiles>

Au13

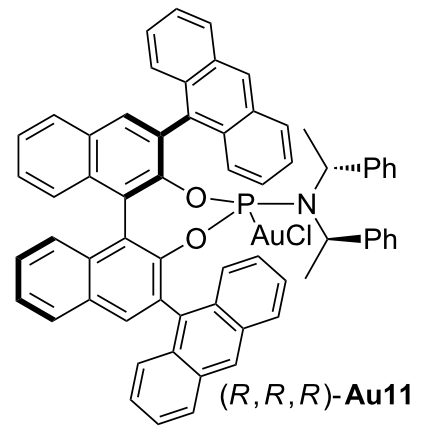

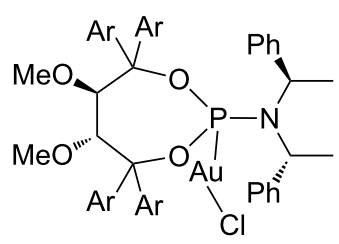

$(R, R, R, R)$-Au8, Ar: 4-t-Bu-Ph<smiles></smiles>

\begin{tabular}{|c|c|c|c|c|c|}
\hline$x$ & $n$ & $\mathrm{R}^{1}$ & $\mathrm{R}^{2}$ & yield & ee \\
\hline NTs & 1 & & $82 \%$ & $91 \%[a]$ \\
\hline NTs & 1 & \multicolumn{2}{|c|}{$-\left(\mathrm{CH}_{2}\right)_{4}^{-}$} & $91 \%$ & $99 \%{ }^{[b]}$ \\
\hline NTs & 1 & $\mathrm{Me}$ & $\mathrm{Me}$ & $93 \%$ & $92 \%$ [a] \\
\hline NTs & 1 & $\mathrm{Me}$ & $\mathrm{Me}$ & $83 \%$ & $99 \%[\mathrm{~b}]$ \\
\hline NTs & 1 & $\mathrm{Me}$ & $\mathrm{Me}$ & $90 \%$ & $91 \%[c]$ \\
\hline NTs & 1 & \multicolumn{2}{|c|}{$-\left(\mathrm{CH}_{2}\right)_{5}^{-}$} & $88 \%$ & $97 \%$ [a] \\
\hline NTs & 2 & $\mathrm{Me}$ & $\mathrm{Me}$ & $90 \%$ & $91 \%$ [a] \\
\hline $\mathrm{C}\left(\mathrm{CO}_{2} \mathrm{Me}\right)_{2}$ & 1 & $\mathrm{Me}$ & $\mathrm{Me}$ & $87 \%$ & $92 \%$ [d] \\
\hline $\mathrm{C}\left(\mathrm{CO}_{2} \mathrm{Me}\right)_{2}$ & 1 & \multicolumn{2}{|c|}{$-\left(\mathrm{CH}_{2}\right)_{5}^{-}$} & $92 \%$ & $82 \%[d]$ \\
\hline
\end{tabular}

[a]With $(R, R, R)$-Au11 (10\%)/AgSbF 6 (10\%), $\mathrm{CH}_{2} \mathrm{Cl}_{2},-15^{\circ} \mathrm{C}$; ${ }^{[\mathrm{b}]}$ with $(S, S, S)$-Au12 $(5 \%) / \mathrm{AgSbF}_{6}(5 \%), \mathrm{CH}_{2} \mathrm{Cl}_{2},-15^{\circ} \mathrm{C}$; ${ }^{[c]}$ with Au8 (5.5\%)/AgBF 4 (5\%), $\mathrm{CH}_{2} \mathrm{Cl}_{2}, 0^{\circ} \mathrm{C}$; [d] with Au13 $(5 \%) / \mathrm{AgBF}_{4}(5 \%)$, benzene, rt

Scheme 9: Gold-catalyzed enantioselective [4 +2$]$ cycloadditions of allenedienes.

DFT calculations indicated that the activation barriers for the ring-contraction process leading to these six-membered systems, and the 1,2-H shifts that retain that seven-membered ring, are quite similar [60]. Therefore, it seemed plausible that this type of chiral catalysts could also provide an enantioselective entry to the seven-membered adducts of type $\mathbf{1 4}$, provided that the ring-contraction route could be slightly deactivated. The viability of this hypothesis was validated by Mascareñas, López and co-workers, demonstrating that terminally monosubstituted allenes, which provide carbene intermediates that are less prone to undergo a ring contraction (VIII, Scheme 8), react with phos-

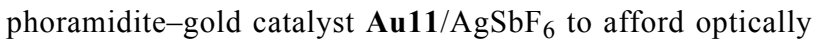
active, synthetically relevant bicyclo[5.3.0]decadiene and bicyclo[5.4.0] undecadiene skeletons $\mathbf{1 4}$ with good yields, complete diastereocontrol and excellent enantioselectivities (Scheme 10) [68]. The scope of this method, which constituted the first highly enantioselective intramolecular $[4 \mathrm{C}+3 \mathrm{C}]$ cycloaddition promoted by a transition metal complex, encompasses internally monosubstituted allenes, as well as disubstituted counterparts, offering a direct entry to 5,7 bicyclic systems including those with all-carbon quaternary stereocenters at the ring fusion.
In contrast to the intramolecular counterpart, gold-catalyzed intermolecular cycloadditions of allenes have been scarcely studied. However, significant progress has been made in the last 4 years. While the development of an intermolecular [4 +3] cycloaddition between allenes and dienes remains elusive, neither in a racemic nor enantioselective fashion [69], it has been shown that allenamides [70] or allenyl ethers [71] participate as two-carbon atom components in several gold-catalyzed [4 +2] cycloadditions with dienes. The racemic version of the reaction between allenamides and dienes, which is efficiently promoted by $\mathrm{AuCl}$ or the cationic gold catalyst $\mathbf{A u 9} / \mathrm{AgSbF}_{6}$, was translated into a enantioselective version by using a novel chiral gold complex Au14, featuring a triazole unit embedded in a rigid axially chiral cyclic frame (Scheme 11) [72]. The catalyst generated from Au14 and $\mathrm{AgNTf}_{2}$ was able to promote the $[4+2]$ cycloaddition between allenamides $\mathbf{1 6}$ and conjugated dienes 17 with total regio- and stereoselectivity and excellent enantioselectivity. The method provides a versatile and practical approach to a variety of optically active cyclohexene products like 18. Importantly, the scope of the asymmetric process is even wider than that of the racemic reaction [70], allowing the construction of six-membered adducts with up to three new 


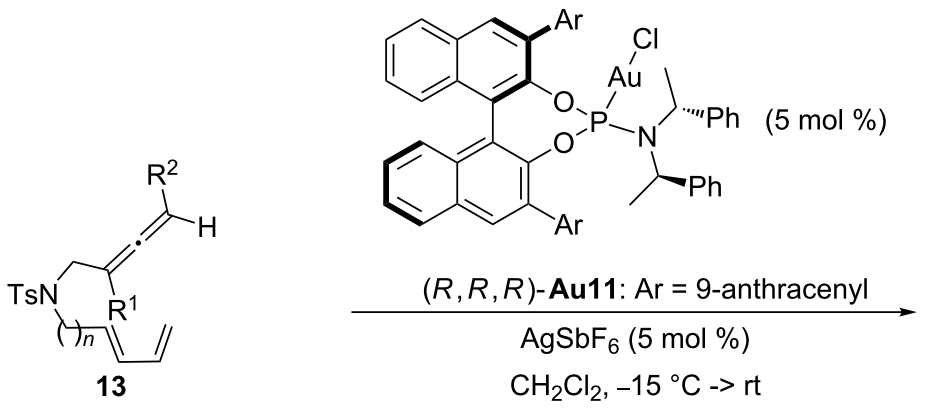

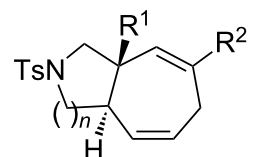

14

\begin{tabular}{lllrl}
\hline$n$ & $\mathrm{R}^{1}$ & $\mathrm{R}^{2}$ & yield & ee \\
\hline 1 & $\mathrm{H}$ & $\mathrm{Ph}$ & $74 \%$ & $95 \%$ \\
1 & $\mathrm{H}$ & o-MePh & $68 \%$ & $95 \%$ \\
1 & $\mathrm{H}$ & $m$-MePh & $75 \%$ & $95 \%$ \\
1 & $\mathrm{H}$ & o-MeOPh & $80 \%$ & $98 \%$ \\
1 & $\mathrm{Me}$ & $\mathrm{Me}$ & $78 \%$ & $95 \%$ \\
1 & $\mathrm{Me}$ & $\mathrm{iPr}$ & $76 \%$ & $95 \%$ \\
2 & $\mathrm{Me}$ & $\mathrm{Me}$ & $95 \%$ & $98 \%$ \\
\hline
\end{tabular}<smiles>[R]C=CN1CCOC1=O</smiles>

16<smiles>[Y]C=CC(=CC)[N+]1=CCCC1=O</smiles>

Gold-activated allenamide species that are proposed to operate in these cycloadditions<smiles>[R]C=CC([R])=C[R]</smiles>

17
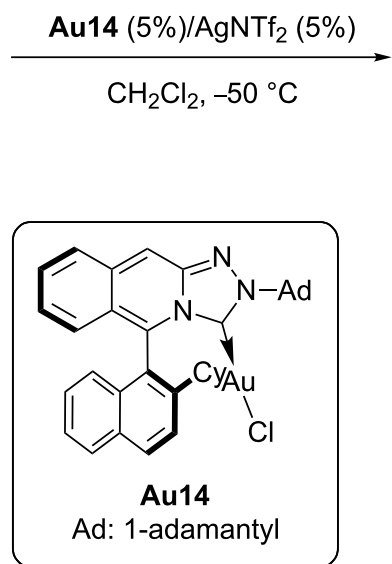<smiles>[R]C1=CC([R])C([R])C(=CN2CCOC2=O)C1[R]</smiles>

\begin{tabular}{llllll}
\hline $\mathrm{R}^{1}$ & $\mathrm{R}^{2}$ & $\mathrm{R}^{3}$ & $\mathrm{R}^{4}$ & yield & ee \\
\hline $\mathrm{H}$ & $\mathrm{H}$ & $\mathrm{H}$ & $\mathrm{Ph}$ & $82 \%$ & $94 \%$ \\
$\mathrm{H}$ & $\mathrm{H}$ & $\mathrm{Me}$ & $\mathrm{Ph}$ & $88 \%$ & $95 \%$ \\
$\mathrm{H}$ & $\mathrm{Me}$ & $\mathrm{H}$ & $\mathrm{Ph}$ & $85 \%$ & $94 \%$ \\
$\mathrm{H}$ & $\mathrm{H}$ & $\mathrm{H}$ & $\mathrm{Me}$ & $71 \%$ & $91 \%$ \\
$\mathrm{H}$ & $\mathrm{Me}$ & $\mathrm{H}$ & $\mathrm{Me}$ & $56 \%$ & $87 \%$ \\
$\mathrm{Me}$ & $\mathrm{H}$ & $\mathrm{Me}$ & $\mathrm{Ph}$ & $75 \%$ & $96 \%[\mathrm{a}]$ \\
$\mathrm{Me}$ & $\mathrm{Me}$ & $\mathrm{H}$ & $\mathrm{Ph}$ & $51 \%$ & $91 \%[\mathrm{~b}]$
\end{tabular}

[a] Carried out from -50 to $-15{ }^{\circ} \mathrm{C} ; \mathrm{dr}=6: 1$; ${ }^{[b]}$ carried out at $10^{\circ} \mathrm{C}$

Scheme 11: Gold-catalyzed enantioselective [4 + 2] cycloadditions of allenamides.

stereogenic centers with complete diastereoselectivity and enantioselectivities of up to $91 \%$ ee $\left(R^{1}, R^{2}=M e, R^{4}=P h\right.$, Scheme 11). With regard to the mechanism, it has been proposed that the activation of the allenamide by the gold catalyst provides a gold-allyl cationic species of type IX, which is the species undergoing the cycloaddition process with the diene [73].

Simple alkenes do also react with gold-activated allenamides to provide cyclobutane products, formally resulting from a $[2+2]$ cycloaddition. Thus, independent investigations by the groups of Mascareñas, González and Chen revealed that the goldcatalyzed cycloaddition between an allenamide and an appropriate alkene (e.g., enamide, enol ether or vinylarene) provides a variety of cyclobutanic systems in excellent yields. The optimum catalysts for the racemic processes include a phosphite-gold complex Au10 and a biaryldi-tert-butylphosphine-gold complex (Au3) [74-76]. More recently, González and co-workers accomplished the enantioselective version of these annulations between sulfonyl allenamides and 


\begin{tabular}{llllll}
\hline & & & & \\
\end{tabular}

Scheme 12: Enantioselective [2 + 2] cycloadditions of allenamides.

vinylarenes, providing a straightforward entry into optically active cyclobutanes [77]. Several chiral phosphoramidite-gold complexes, such as $(S, R, R)$-Au7, $(S, R, R)$-Au15 and $(R, R, R)$ Au16, derived from Siphos, Binol and Vanol, respectively, provided excellent enantioselectivities, displaying useful complementarity in some of the cases. Importantly, the method also allowed the preparation of cyclobutanes $\mathbf{2 0}$ containing challenging quaternary carbon centers (Scheme 12).

From a mechanistic point of view, these [2+2] cycloadditions, either in racemic or asymmetric versions, have been proposed to proceed through a stepwise cationic pathway consisting of an initial activation of the allene to provide an Au-allyl cationic species, followed by a regioselective interception by the alkene to give a second cationic intermediate (X, Scheme 13) [73]. The substituent at the alkene ( $\mathrm{R}^{1}$, Scheme 13$)$, either an aryl, nitrogen or oxygen-group, plays a key role in the stabilization of this intermediate and therefore facilitates the overall process. Finally, a ring-closing process through attack of the vinylgold species to the stabilized carbocation yields the cyclobutane system and regenerates the catalyst.

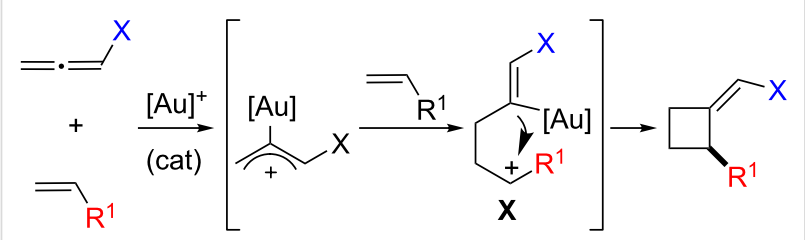

$X=$ NCOR or OR; $R^{1}: A r, N C O R$ or OR

Scheme 13: Mechanistic rational for the gold-catalyzed [2 + 2] cycloadditions.
In view of this mechanistic proposal, Mascareñas and López recently developed a gold-catalyzed cascade cycloaddition between allenamides and carbonyl-tethered alkenes $\mathbf{2 1}$, including an enantioselective variant, that provides synthetically appealing oxa-bridged seven, eight and even ninemembered rings (22, Scheme 14) [78]. The cascade process relies on the interception of intermediates of type $\mathbf{X}$ by an intramolecular carbonyl group, followed by the ring closing of the resulting oxonium intermediate XI. The reaction occurs at low temperatures by using only $1 \mathrm{~mol} \%$ of a phosphite-based gold catalyst. The enantioselective version, which is catalyzed by the DTBM-Segphos complex Au1/AgNTf 2 , or the phosphoramidite-gold complex $(S, R, R)$-Au16/AgNTf 2 , provides the corresponding cycloadducts $\mathbf{2 2}$ with good or high enantioselectivites (Scheme 14). The method constituted the first direct catalytic and enantioselective entry to oxygen-bridged eightmembered carbocycles and one of the few methods that affords optically active cyclooctanes by means of a catalytic enantioselective process.

Also recently, Chen and co-workers demonstrated that goldactivated allenamide species can participate in $[3+2]$ cycloadditions with azomethine imines or nitrones under catalysis with $\mathrm{Ph}_{3} \mathrm{PAuCl} / \mathrm{AgOTf}$ or $\mathrm{Ph}_{3} \mathrm{PAuCl} / \mathrm{AgNTf}_{2}$ [79,80]. Moreover, for the latter cycloaddition with nitrones, the authors reported a enantioselective variant by using chiral phosphoramidite-gold complexes. In these cases, the binol-derived complexes, with aryl substituents at the 3 and 3 ' positions, turned out to be the optimal systems, providing the corresponding 4-alkylidenylisoxazolidine derivatives $\mathbf{2 3}$ in high yields and excellent enantioselectivities. The highest enantioselectivities were obtained with $(R, R, R)$-Au17 and $(R, S, S)$-Au18, which include 9-phenantrenyl or 4-biphenyl units in these binol ortho-positions, respectively (Scheme 15). Further derivatization of the products led to enantio-enriched 1,3-aminoalcohols. 
<smiles>C=CN1CCCC1=O</smiles>

16<smiles>[R]C=C(NCC([R])=O)c1ccccc1</smiles>

21

[Au] cat.<smiles>[R20]C=C1CC([R])C(C)(c2ccccc2)OC1([R])CC</smiles>

22

\begin{tabular}{lllll}
\hline $\mathrm{R}^{1}$ & $\mathrm{R}^{2}$ & $n$ & yield & ee \\
\hline $\mathrm{H}$ & $\mathrm{Me}$ & 1 & $63 \%$ & $66 \% \%^{[a]}$ \\
$\mathrm{H}$ & $\mathrm{Ph}$ & 1 & $69 \%$ & $64 \% \%^{[a]}$ \\
$\mathrm{H}$ & $\mathrm{H}$ & 1 & $83 \%$ & $68 \%$ [a] $^{[a]}$ \\
$\mathrm{Me}$ & $\mathrm{Me}$ & 1 & $72 \%$ & $80 \%[\mathrm{[a]}$ \\
$\mathrm{H}$ & $\mathrm{Me}$ & 2 & $52 \%$ & $90 \%[\mathrm{~b}]$ \\
$\mathrm{H}$ & $\mathrm{Ph}$ & 2 & $80 \%$ & $82 \%[\mathrm{~b}]$ \\
$\mathrm{Me}$ & $\mathrm{Me}$ & 2 & $45 \%$ & $92 \%[\mathrm{~b}]$ \\
\hline
\end{tabular}

[a]With (R)-Au1 (5\%)/AgNTf 2 (5\%), $\mathrm{CH}_{2} \mathrm{Cl}_{2},-78^{\circ} \mathrm{C}$; ${ }^{[b]}$ with $(S, R, R)$-Au16 (5\%)/AgNTf 2 (5\%), $\mathrm{CH}_{2} \mathrm{Cl}_{2},-78$ to $-35^{\circ} \mathrm{C}$

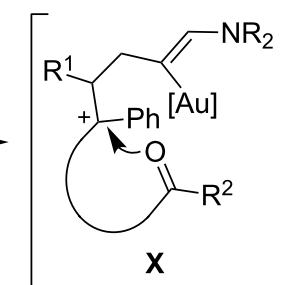

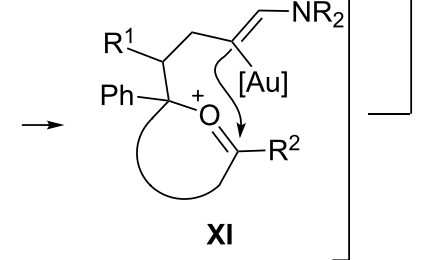

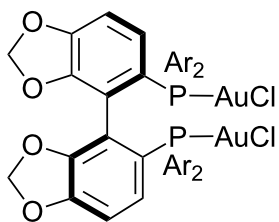

$(R)$-Au1

[DTBM-Segphos $\left.(\mathrm{AuCl})_{2}\right]$ $\mathrm{Ar}=3,5-t-\mathrm{Bu}-4-\left(\mathrm{CH}_{3} \mathrm{O}\right)-\mathrm{C}_{6} \mathrm{H}_{2}$<smiles>CC(c1ccccc1)N(C(Cl)(Cl)c1ccccc1)P(=O)(Oc1c2ccccc2cc2ccccc12)c1ccccc1</smiles>

$(S, R, R)$-Au16

Scheme 14: Enantioselective cascade cycloadditions between allenamides and oxoalkenes.

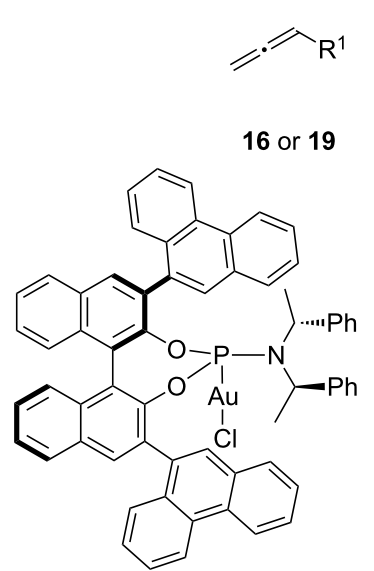

$(R, R, R)$-Au17

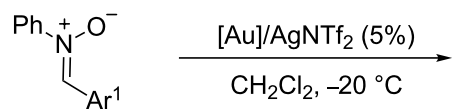

$\mathrm{CH}_{2} \mathrm{Cl}_{2},-20^{\circ} \mathrm{C}$<smiles>[Y]C1C2=CC=C(CO2)N1c1ccccc1</smiles>

$23 \mathrm{R}^{1}$<smiles>CC(c1ccccc1)N(C(C)c1ccccc1)[PH](Cl)(Oc1c(-c2ccccc2)cc2ccccc2c1-c1ccc(-c2ccccc2)cc1)Oc1c(-c2ccccc2)ccc2ccccc12</smiles>

$(R, S, S)$-Au18 \begin{tabular}{llll}
\hline $\mathrm{R}^{1}$ & $\mathrm{Ar}^{1}$ & yield & ee \\
\hline $\mathrm{N}(\mathrm{Ts}) \mathrm{Bn}$ & $\mathrm{Ph}$ & $99 \%$ & $99 \%[\mathrm{a}]$ \\
$\mathrm{N}(\mathrm{Ts}) \mathrm{Bn}$ & $p-\mathrm{BrPh}$ & $98 \%$ & $98 \%[\mathrm{a}]$ \\
$\mathrm{N}(\mathrm{Ts}) \mathrm{Bn}$ & $p-\mathrm{MePh} 99 \%$ & $98 \%[\mathrm{a}]$ \\
$\mathrm{N}(\mathrm{Ts}) \mathrm{Ph}$ & $\mathrm{Ph}$ & $88 \%$ & $94 \%[\mathrm{a}]$ \\
$\mathrm{N}(\mathrm{Ts}) \mathrm{Bn}$ & $m-\mathrm{ClPh}$ & $99 \%$ & $97 \%[\mathrm{a}]$ \\
$\mathrm{N}(\mathrm{Ts}) \mathrm{Bn}$ & $2-\mathrm{Naph}$ & $92 \%$ & $99 \%[\mathrm{a}]$
\end{tabular}

(5\%), $\mathrm{CH}_{2} \mathrm{Cl}_{2},-20^{\circ} \mathrm{C}$; ${ }^{[b]}$ with

$(R, S, S)$-Au18 (2\%)/AgNTf 2 (5\%),

$\mathrm{CH}_{2} \mathrm{Cl}_{2},-20^{\circ} \mathrm{C}$

Scheme 15: Enantioselective [3 + 2] cycloadditions of nitrones and allenamides.

Other reactions involving zwitterionic alkenylgold intermediates

The gold-bound allyl cation species generated from allenes could be formally viewed as 1,2 or 1,3-zwitterionic cycloaddi- tion components. In a recent paper, Liu and co-workers demonstrated that 1,6-enynes like $\mathbf{2 4}$ when treated with appropriated gold complexes lead to related 1,4-zwitterionic homologs that can be efficiently intercepted by nitrones in a formal [ $4+3]$ cy- 
cloaddition reaction. The resulting 1,2-oxazepane derivatives 25 are isolated as single diastereoisomers with high enantioselectivities (84-95\% ee) [81]. Optimal conditions for the enantioselective variant of the process involved the use of the chiral gold complex Au5 (3.8 mol \%), derived from MeO-DTBMBiphep, in combination with AgOTf. The requirement of equimolar amounts of the silver salt and the bisgold complex suggests that only one $\mathrm{Au}-\mathrm{Cl}$ bond remains intact in the gold catalyst (Scheme 16). From a mechanistic point of view, the authors proposed that the intermediate species can be viewed as either a cyclopropylgold carbenoid XII or as a zwitterionic alkenylgold derivative XII', the latter being the species that participates in the cycloaddition to the nitrone, probably in a concerted pathway, and thus providing the corresponding products with high levels of stereoselectivity $[82,83]$.

Previously, in 2009, J. Zhang had reported a gold(I)-catalyzed 1,3-dipolar [3 + 3] cycloaddition between 2-(1-alkynyl)-2alken-1-ones 26 and nitrones. The reactions provide fused heterobicyclic oxazine derivatives of type $\mathbf{2 7}$ with good yields and excellent regio- and diastereoselectivities. The racemic series, promoted by $\mathrm{Ph}_{3} \mathrm{PAuCl} / \mathrm{AgOTf}$ as a catalyst [84], was translated into an enantioselective version by using any of the chiral bisgold complexes derived from $(R)$-C1-Tunephos (Au19) or (R)-MeO-DTBM-Biphep (Au5) (Scheme 17) [85]. From a mechanistic point of view, the authors proposed the generation of a zwitterionic furanylgold complex of type XIII by a gold-promoted intramolecular cyclization process. This key intermediate is then trapped by the nitrone to afford XIV, which eventually evolves to the product by an intramolecular cyclization (Scheme 17).

Finally, the same group recently reported a related reaction of 1-(1-alkynyl)cyclopropyl ketones such as $\mathbf{2 8}$, by means of a gold(I)-catalyzed asymmetric [4+3] cycloaddition. In this article, the authors demonstrated that a chiral gold catalyst generated from MeO-DTBM-Biphep was able to promote the $[4+3]$ cycloaddition between ketone $\mathbf{2 8}$ and the nitrone $\mathbf{2 9}$, to afford the corresponding 5,7-fused bicyclic furo[3,4d] [1,2] oxazepine $\mathbf{3 0}$ in good yield, high diastereoselectivity (dr 11:1) and excellent 91\% ee (Scheme 18) [86-88]. However, the extension of this method to 1-(1-alkynyl)cyclopropyl ketones and nitrones others than $\mathbf{2 8}$ and $\mathbf{2 9}$ remains to be demonstrated.

\section{Conclusion}

In the last years there have been remarkable advances in the development of enantioselective gold(I)-catalyzed cycloadditions. Although the area is still in its infancy, there is enough evidence to predict that the number of examples will steadily increase in the near future. It would be highly desirable to have more information on the precise factors that govern the enantioselectivity process, as this will facilitate the design of new asymmetric processes.

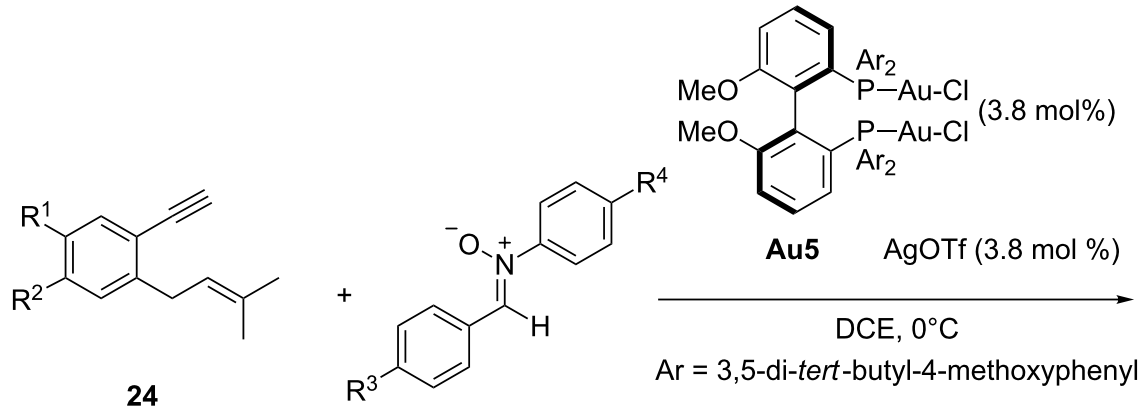<smiles>[R4]c1ccc([C@@H]2C=C3c4cc([R])c([R])cc4C[C@H]3C(C)(C)ON2c2ccc([R])cc2)cc1</smiles>

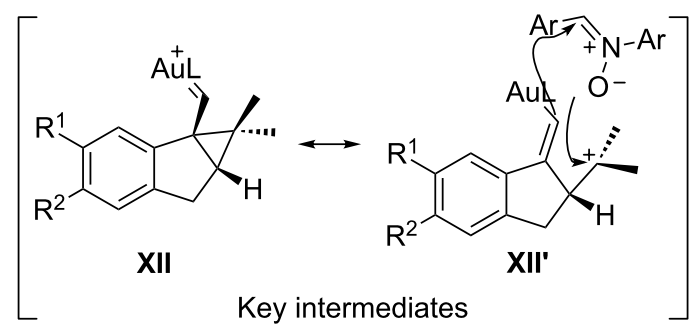

\begin{tabular}{llllll}
\hline $\mathrm{R}^{1}$ & $\mathrm{R}^{2}$ & $\mathrm{R}^{3}$ & $\mathrm{R}^{4}$ & yield & ee \\
\hline $\mathrm{H}$ & $\mathrm{H}$ & $\mathrm{H}$ & $\mathrm{H}$ & $82 \%$ & $95 \%$ \\
$\mathrm{OMe}$ & $\mathrm{H}$ & $\mathrm{H}$ & $76 \%$ & $95 \%$ \\
$\mathrm{H}$ & $\mathrm{OMe}$ & $\mathrm{H}$ & $78 \%$ & $94 \%$ \\
$\mathrm{Cl}$ & $\mathrm{H}$ & $\mathrm{H}$ & $\mathrm{H}$ & $80 \%$ & $89 \%$ \\
$\mathrm{H}$ & $\mathrm{Cl}$ & $\mathrm{H}$ & $\mathrm{H}$ & $77 \%$ & $90 \%$ \\
$\mathrm{H}$ & $\mathrm{H}$ & $\mathrm{NO}_{2}$ & $\mathrm{H}$ & $79 \%$ & $93 \%$ \\
$\mathrm{H}$ & $\mathrm{H}$ & $\mathrm{H}$ & $\mathrm{OMe}$ & $73 \%$ & $89 \%$ \\
\hline
\end{tabular}




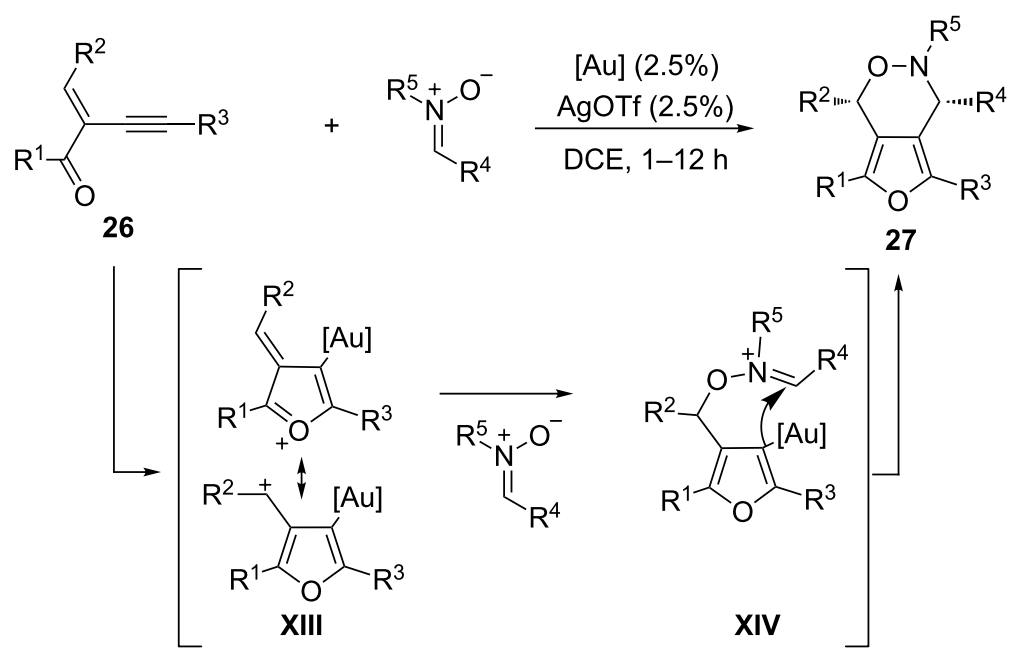

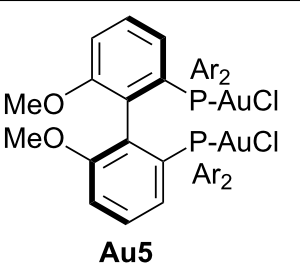

Ar: 3,5-t-Bu-4-MeOC ${ }_{6} \mathrm{H}_{2}$

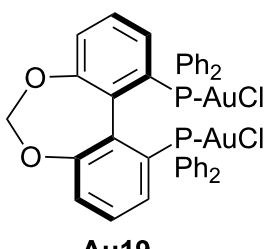

Au19

$(R)-\mathrm{C}_{1}$-Tunephos $(\mathrm{AuCl})_{2}$

\begin{tabular}{llllll}
$\mathrm{R}^{1}$ & $\mathrm{R}^{2}$ & $\mathrm{R}^{3}$ & $\mathrm{R}^{4}$ & yield & ee \\
\hline $\mathrm{Me}$ & $\mathrm{Ph}$ & $\mathrm{Ph}$ & $p-\mathrm{BrPh}$ & $95 \%$ & $95 \%{ }^{[\mathrm{a}]}$ \\
$\mathrm{Me}$ & $\mathrm{Ph}$ & $p-\mathrm{MeOPh}$ & $\mathrm{Ph}$ & $72 \%$ & $96 \%{ }^{[\mathrm{b}]}$ \\
$\mathrm{Ph}$ & $\mathrm{Ph}$ & $\mathrm{Ph}$ & $\mathrm{Ph}$ & $92 \%$ & $93 \%{ }^{[\mathrm{b}]}$ \\
$\mathrm{Ph}$ & $\mathrm{Ph}$ & $\mathrm{Ph}$ & $\mathrm{Ph}$ & $94 \%$ & $98 \%{ }^{[\mathrm{a}]}$ \\
$\mathrm{Me}$ & $\mathrm{Ph}$ & $n-\mathrm{Bu}$ & $\mathrm{Ph}$ & $77 \%$ & $\left.55 \%{ }^{[\mathrm{b}}\right]$ \\
$\mathrm{Me}$ & $\mathrm{Ph}$ & $n-\mathrm{Bu}$ & $\mathrm{Ph}$ & $59 \%$ & $\left.32 \%{ }^{[\mathrm{a}}\right]$ \\
\hline
\end{tabular}

[a]With (R)-Au5 (2.5\%)/AgOTf (2.5\%),

DCE, $-0{ }^{\circ} \mathrm{C}$; ${ }^{[\mathrm{b}]}$ with $(R)$-Au19 (2.5\%)/AgOTf $(2.5 \%)$, DCE, $-30{ }^{\circ} \mathrm{C}$

Scheme 17: Enantioselective gold(I)-catalyzed 1,3-dipolar [3 + 3] cycloaddition between 2-(1-alkynyl)-2-alken-1-ones and nitrones<smiles>CC(=O)C1(C#C[18F])C[C@@H]1P</smiles>

28<smiles>[O-]/[N+](=C\c1ccccc1)c1ccccc1</smiles>

29

\begin{tabular}{c}
$\begin{array}{c}\text { MeO-DTBM BIPHEP (3\%) } \\
\text { AuCl.SMe }_{2}(5 \%)\end{array}$ \\
\hline AgOTf $(5 \%)$ \\
DCE, $1-12 \mathrm{~h}$
\end{tabular}

DCE, 1-12 h

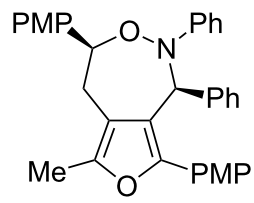

$30,87 \%, 91 \%$ ee $\mathrm{dr}=11: 1$
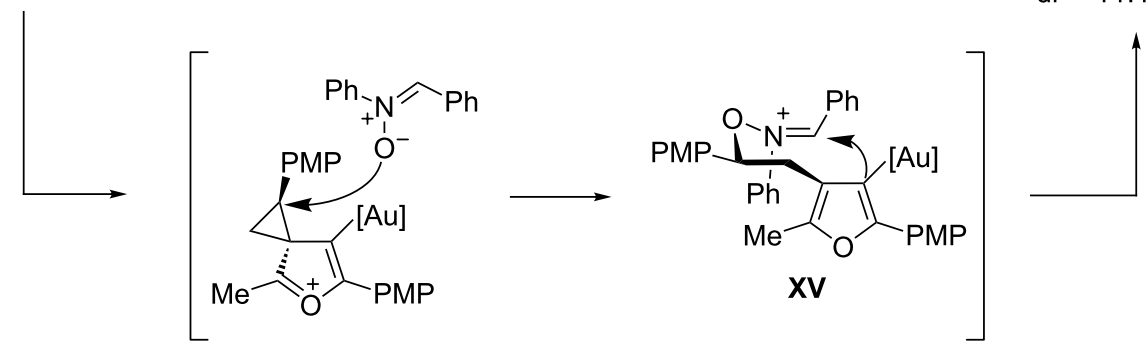

Scheme 18: Enantioselective [4 + 3] cycloaddition leading to 5,7-fused bicyclic furo[3,4- $d][1,2]$ oxazepines.

\section{Acknowledgements}

Our work in the area is supported by the Spanish MINECO [SAF2010-20822-c02-01/02, and Consolider-Ingenio 2010 (CSD2007-00006)], CSIC and Xunta de Galicia (GRC2010/12, INCITE09 209122 PR, GRC2013-041), as well as the ERDF.

\section{References}

1. Hashmi, A. S. K.; Toste, F. D., Eds. Modern Gold Catalyzed Synthesis; Wiley-VCH: Weinheim, Germany, 2012.

2. Rudolph, M.; Hashmi, A. S. K. Chem. Soc. Rev. 2012, 41, 2448. doi:10.1039/c1cs15279c 
3. Liu, L.-P.; Hammond, G. B. Chem. Soc. Rev. 2012, 41, 3129. doi:10.1039/c2cs15318a

4. Krause, N.; Winter, C. Chem. Rev. 2011, 111, 1994. doi:10.1021/cr1004088

5. Corma, A.; Leyva-Perez, A.; Sabater, M. J. Chem. Rev. 2011, 111, 1657. doi:10.1021/cr100414u

6. Abu Sohel, S. Md.; Liu, R.-S. Chem. Soc. Rev. 2009, 38, 2269. doi:10.1039/b807499m

7. Gorin, D. J.; Sherry, B. D.; Toste, F. D. Chem. Rev. 2008, 108, 3351. doi:10.1021/cr068430g

8. Jiménez-Núñez, E.; Echavarren, A. M. Chem. Rev. 2008, 108, 3326. doi:10.1021/cr0684319

9. Arcadi, A. Chem. Rev. 2008, 108, 3266. doi:10.1021/cr068435d

10. Hashmi, A. S. K. Chem. Rev. 2007, 107, 3180. doi:10.1021/cr000436x

11. Widenhoefer, R. A. Chem.-Eur. J. 2008, 14, 5382. doi:10.1002/chem.200800219

12. Gorin, D. J.; Toste, F. D. Nature 2007, 446, 395 doi:10.1038/nature05592

13. Sengupta, S.; Shi, X. ChemCatChem 2010, 2, 609. doi: $10.1002 /$ cctc. 201000070

14. Pradal, A.; Toullec, P. Y.; Michelet, V. Synthesis 2011, 1501. doi:10.1055/s-0030-1258465

15. Muñoz, M. P.; Adrio, J.; Carretero, J. C.; Echavarren, A. M. Organometallics 2005, 24, 1293. doi:10.1021/om0491645 See for the pioneer development of new chiral carbophilic gold complexes.

16. Hamilton, G. L.; Kang, E. J.; Mba, M.; Toste, F. D. Science 2007, 317, 496. doi:10.1126/science. 1145229

17. Carruthers, W. Cycloaddition Reactions in Organic Synthesis; Pergamon: Oxford, 1990.

18. Kobayashi, S.; Jorgensen, K. A. Cycloaddition Reactions in Organic Synthesis; Wiley-VCH: Weinheim, Germany, 2002.

19. Lautens, M.; Klute, W.; Tam, W. Chem. Rev. 1996, 96, 49. doi:10.1021/cr950016I

20. Pellissier, H. Adv. Synth. Catal. 2011, 353, 189. doi:10.1002/adsc.201000695

21. Butenschön, H. Angew. Chem., Int. Ed. 2008, 47, 5287. doi:10.1002/anie.200801738

22. Gulias, M.; López, F.; Mascareñas, J. L. Pure Appl. Chem. 2011, 83, 495. doi:10.1351/PAC-CON-10-10-23

23. Inglesby, P. A.; Evans, P. A. Chem. Soc. Rev. 2010, 39, 2791. doi:10.1039/b913110h

24. López, F.; Mascareñas, J. L. Beilstein J. Org. Chem. 2011, 7, 1075. doi:10.3762/bjoc.7.124

25. Shen, H. C. Tetrahedron 2008, 64, 7847. doi:10.1016/j.tet.2008.05.082

26. Garayalde, D.; Nevado, C. ACS Catal. 2012, 2, 1462. doi:10.1021/cs300043w

27. Marinetti, A.; Jullien, H.; Voituriez, A. Chem. Soc. Rev. 2012, 41, 4884. doi:10.1039/c2cs35020c

See for a review covering transition metal catalyzed enantioselective cycloadditions.

28. Melhado, A. D.; Amarante, G. W.; Wang, Z. J.; Luparia, M.; Toste, F. D. J. Am. Chem. Soc. 2011, 133, 3517. doi:10.1021/ja1095045

29. Melhado, A. D.; Luparia, M.; Toste, F. D. J. Am. Chem. Soc. 2007, 129, 12638. doi:10.1021/ja074824t

30. Martín-Rodríguez, M.; Nájera, C.; Sansano, J. M.; Wu, F.-L. Tetrahedron: Asymmetry 2010, 21, 1184. doi:10.1016/j.tetasy.2010.06.011
31. Martín-Rodríguez, M.; Nájera, C.; Sansano, J. M.; de Cózar, A.; Cossío, F. P. Beilstein J. Org. Chem. 2011, 7, 988. doi:10.3762/bjoc.7.111

32. Liu, B.; Li, K.-N.; Luo, S.-W.; Huang, J.-Z.; Pang, H.; Gong, L.-Z. J. Am. Chem. Soc. 2013, 135, 3323. doi:10.1021/ja3110472

33. Benitez, D.; Shapiro, N. D.; Tkatchouk, N.; Wang, Y.; Goddard, W. A., III; Toste, F. D. Nat. Chem. 2009, 1, 482. doi:10.1038/nchem.331

Many Au-carbene species can also be understood as Au-stabilized carbocations.

34. Seidel, G.; Mynott, R.; Fürstner, A. Angew. Chem., Int. Ed. 2009, 48, 2510. doi:10.1002/anie.200806059

35. Fürstner, A.; Morency, L. Angew. Chem., Int. Ed. 2008, 47, 5030. doi:10.1002/anie.200800934

36. Nieto-Oberhuber, C.; Muñoz, M. P.; Buñuel, E.; Nevado, C.; Cárdenas, D. J.; Echavarren, A. M. Angew. Chem., Int. Ed. 2004, 43, 2402. doi:10.1002/anie.200353207

37. Echavarren, A. Nat. Chem. 2009, 1, 431. doi:10.1038/nchem.344

38. Correa, A.; Marion, N.; Fensterbank, L.; Malacria, M.; Nolan, S. P.; Cavallo, L. Angew. Chem., Int. Ed. 2008, 47, 718. doi:10.1002/anie.200703769

39. Marion, N.; Nolan, S. P. Angew. Chem., Int. Ed. 2007, 46, 2750. doi:10.1002/anie.200604773

40. Marco-Contelles, J.; Soriano, E. Chem.-Eur. J. 2007, 13, 1350. doi:10.1002/chem.200601522

41. Johansson, M. J.; Gorin, D. J.; Staben, S. T.; Toste, F. D. J. Am. Chem. Soc. 2005, 127, 18002. doi:10.1021/ja0552500

42. Watson, I. D. G.; Ritter, S.; Toste, F. D. J. Am. Chem. Soc. 2009, 131, 2056. doi:10.1021/ja8085005

43. Garayalde, D.; Krüger, K.; Nevado, C. Angew. Chem., Int. Ed. 2011, 50, 911. doi:10.1002/anie.201006105

44. Fructos, M. R.; Belderrain, T. R.; de Fremont, P.; Scott, N. M.; Nolan, S. P.; Díaz-Requejo, M. M.; Pérez, P. J. Angew. Chem., Int. Ed. 2005, 44, 5284. doi:10.1002/anie.200501056

45. Prieto, A.; Fructos, M. R.; Díaz-Requejo, M. M.; Pérez, P. J.; Pérez-Galán, P.; Delpont, N.; Echavarren, A. M. Tetrahedron 2009, 65, 1790. doi:10.1016/j.tet.2008.10.114

46. Briones, J. F.; Davies, H. M. L. J. Am. Chem. Soc. 2012, 134, 11916. doi:10.1021/ja304506g

47. Cao, Z.-Y.; Wang, X.; Tan, C.; Zhao, X.-L.; Zhou, J.; Ding, K. J. Am. Chem. Soc. 2013, 135, 8197. doi:10.1021/ja4040895

48. Gandon, V.; Lemière, G.; Hours, A.; Fensterbank, L.; Malacria, M. Angew. Chem., Int. Ed. 2008, 47, 7534. doi:10.1002/anie.200802332

49. Luzung, M. R.; Mauleón, P.; Toste, F. D. J. Am. Chem. Soc. 2007, 129, 12402. doi:10.1021/ja075412n

50. Recent theoretical computations indicate that the intermediate of type VI, could be better described as VI', where the gold center establishes a stabilizing electrostatic interaction with the benzylic carbocation. See reference [51].

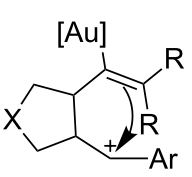

VI<smiles>[X]CC1C(=C([R])[R])C2[Y19](Br)CCC12</smiles>

V'
51. González, A. Z.; Benitez, D.; Tkatchouk, E.; Goddard, W. A.; Toste, F. D. J. Am. Chem. Soc. 2011, 133, 5500. doi:10.1021/ja200084a 
52. Teller, H.; Flügge, S.; Goddard, R.; Fürstner, A. Angew. Chem., Int. Ed. 2010, 49, 1949. doi:10.1002/anie.200906550

53. Teller, H.; Corbet, M.; Mantilli, L.; Gopakumar, G.; Goddard, R.; Thiel, W.; Fürstner, A. J. Am. Chem. Soc. 2012, 134, 15331. doi:10.1021/ja303641p

54. Trillo, B.; López, F.; Gulías, M.; Castedo, L.; Mascareñas, J. L. Angew. Chem., Int. Ed. 2008, 47, 951. doi:10.1002/anie.200704566

55. Harmata, M. Chem. Commun. 2010, 46, 8904. doi:10.1039/c0cc03621h

56. Harmata, M. Chem. Commun. 2010, 46, 8886. doi:10.1039/c0cc03620j

57. Fernández, I.; Cossío, F. P.; de Cózar, A.; Lledós, A.; Mascareñas, J. L. Chem.-Eur. J. 2010, 16, 12147. doi:10.1002/chem.201001714

58. Trillo, B.; López, F.; Montserrat, S.; Ujaque, G.; Castedo, L.; Lledós, A.; Mascareñas, J. L. Chem.-Eur. J. 2009, 15, 3336. doi:10.1002/chem.200900164

59. Mauleón, P.; Zeldin, R. M.; González, A. Z.; Toste, F. D. J. Am. Chem. Soc. 2009, 131, 6348. doi:10.1021/ja901649s

60. Alonso, I.; Trillo, B.; López, F.; Montserrat, S.; Ujaque, G.; Castedo, L.; Lledós, A.; Mascareñas, J. L. J. Am. Chem. Soc. 2009, 131, 13020. doi:10.1021/ja905415r

61. Montserrat, S.; Alonso, I.; López, F.; Mascareñas, J. L.; Lledós, A.; Ujaque, G. Dalton Trans. 2011, 40, 11095. doi:10.1039/c1dt11061f

62. Montserrat, S.; Ujaque, G.; López, F.; Mascareñas, J. L.; Lledós, A. Top. Curr. Chem. 2011, 302, 225. doi:10.1007/128_2010_121

63. Benitez, D.; Tkatchouk, E.; Gonzalez, A. Z.; Goddard, W. A., III; Toste, F. D. Org. Lett. 2009, 11, 4798. doi:10.1021/ol9018002

64. Fernández, I.; Mascareñas, J. L. Org. Biomol. Chem. 2012, 10, 699. doi:10.1039/c1ob06604h

65. Teichert, J. F.; Feringa, B. L. Angew. Chem., Int. Ed. 2010, 49, 2486. doi:10.1002/anie.200904948

66. Reetz, M. T.; Guo, H.; Ma, J.-A.; Goddard, R.; Mynott, R. J. J. Am. Chem. Soc. 2009, 131, 4136. doi:10.1021/ja809297a

67. González, A. Z.; Toste, F. D. Org. Lett. 2010, 12, 200. doi:10.1021/ol902622b

68. Alonso, I.; Faustino, H.; López, F.; Mascareñas, J. L. Angew. Chem., Int. Ed. 2011, 50, 11496. doi:10.1002/anie.201105815

69. Gung, B. W.; Bailey, L. N.; Wonser, J. Tetrahedron Lett. 2010, 51 , 2251. doi:10.1016/j.tetlet.2010.02.099

70. Faustino, H.; López, F.; Castedo, L.; Mascareñas, J. L. Chem. Sci. 2011, 2, 633. doi:10.1039/c0sc00630k

71. Wang, G.; Zou, Y.; Li, Z.; Wang, Q.; Goeke, A. Adv. Synth. Catal. 2011, 353, 550. doi:10.1002/adsc.201000597

72. Francos, J.; Grande-Carmona, F.; Faustino, H.; Iglesias-Siguenza, J.; Díez, E.; Alonso, I.; Fernández, R.; Lassaletta, J. M.; López, F.; Mascareñas, J. L. J. Am. Chem. Soc. 2012, 134, 14322. doi:10.1021/ja3065446

73. Montserrat, S.; Faustino, H.; Lledós, A.; Mascareñas, J. L.; López, F.; Ujaque, G. Chem.-Eur. J. 2013, 19, 15248. doi:10.1002/chem.201302330

74. Faustino, H.; Bernal, P.; Castedo, L.; López, F.; Mascareñas, J. L. Adv. Synth. Catal. 2012, 354, 1658. doi:10.1002/adsc.201200047

75. Suárez-Pantiga, S.; Hernández-Díaz, C.; Piedrafita, M.; Rubio, E.; González, J. M. Adv. Synth. Catal. 2012, 354, 1651. doi:10.1002/adsc.201200043

76. Li, X.-X.; Zhu, L.-L.; Zhou, W.; Chen, Z. Org. Lett. 2012, 14, 436. doi:10.1021/ol202703a

77. Suárez-Pantiga, S.; Hernández-Diaz, C.; Rubio, E.; González, J. M. Angew. Chem., Int. Ed. 2012, 51, 11552. doi:10.1002/anie.201206461
78. Faustino, H.; Alonso, I.; Mascareñas, J. L.; López, F. Angew. Chem., Int. Ed. 2013, 52, 6526. doi:10.1002/anie.201302713

79. Zhou, W.; Li, X.-X.; Li, G.-H.; Wu, Y.; Chen, Z. Chem. Commun. 2013, 49, 3552. doi:10.1039/c3cc41258j

80. Li, G.-H.; Zhou, W.; Li, X.-X.; Bi, Q.-W.; Wang, Z.; Zhao, Z.-G.; Hu, W.-X.; Chen, Z. Chem. Commun. 2013, 49, 4770. doi:10.1039/c3cc41769g

81. Gawade, S. A.; Bhunia, S.; Liu, R.-S. Angew. Chem., Int. Ed. 2012, 51, 7835. doi:10.1002/anie.201203507

82. Pradal, A.; Chao, C.-M.; Vitale, M. R.; Toullec, P. Y.; Michelet, V. Tetrahedron 2011, 67, 4371. doi:10.1016/j.tet.2011.03.071

83. Chao, C.-M.; Vitale, M. R.; Toullec, P. Y.; Genêt, J. P.; Michelet, V. Chem.-Eur. J. 2009, 15, 1319. doi:10.1002/chem.200802341 Two isolated examples for related intramolecular enantioselective $[4+2]$ cycloadditions.

84. Liu, F.; Yu, Y.; Zhang, J. Angew. Chem., Int. Ed. 2009, 48, 5505. doi:10.1002/anie.200901299

85. Liu, F.; Qian, D.; Li, L.; Zhao, X.; Zhang, J. Angew. Chem., Int. Ed. 2010, 49, 6669. doi:10.1002/anie.201003136

86. Zhang, Y.; Zhang, J. Chem. Commun. 2012, 48, 4710. doi:10.1039/c2cc30309d

87. Bai, Y.; Fang, J.; Ren, J.; Wang, Z. Chem.-Eur. J. 2009, 15, 8975. doi:10.1002/chem.200901133

For the racemic versions of the previous cycloadditions (reference [86]).

88. Zhang, Y.; Liu, F.; Zhang, J. Chem.-Eur. J. 2010, 16, 6146. doi:10.1002/chem.200903342

\section{License and Terms}

This is an Open Access article under the terms of the Creative Commons Attribution License (http://creativecommons.org/licenses/by/2.0), which permits unrestricted use, distribution, and reproduction in any medium, provided the original work is properly cited.

The license is subject to the Beilstein Journal of Organic Chemistry terms and conditions:

(http://www.beilstein-journals.org/bjoc)

The definitive version of this article is the electronic one which can be found at: doi:10.3762/bjoc.9.264 